\title{
Recovery of Brucella melitensis from Artificially Infected Dromedaries
}

J ohnson $B^{1}$, Kinne $\mathrm{J}^{1}$, J ose Sh${ }^{1}$, Pfeffer $\mathbf{M}^{2}$, Shanmugaraja $\mathbf{R}^{1}$, Pandarakandy $\mathrm{Sh}^{1}$, Ali F , Maio E ${ }^{1}$, Rodriguez Caveney $\mathbf{M}^{1}$, Söllner $\mathrm{NK}^{1}$ and Wernery $\mathbf{U}^{\mathbf{1}} *$

${ }^{1}$ Central Veterinary Research Laboratory, Dubai, United Arab Emirates

${ }^{2}$ Institute for Animal Hygiene, University Leipzig, Germany

*Corresponding author: Wernery U, Central Veterinary Research Laboratory, Dubai, United Arab Emirates

Received: July 11, 2018; Accepted: August 30, 2018; Published: September 06, 2018

\begin{abstract}
Fourteen serological positive dromedaries intratracheally and intranasally infected with Brucella melitensis were euthanased 12 months after infection. A full necropsy was performed on all 14 dromedaries and 43 different organs from each dromedary tested for the presence of the pathogen using 2 selective Brucella media and 3 culture techniques as well as RT PCR.

From a total of 43 different organs 21 (49\%) were culture negative and $22(51 \%)$ positive. The pathogen resided mainly in body lymph nodes. The highest culture result was achieved when the enrichment method was used. However, it is proposed, to use all 3 culture methods (direct, concentrated, enriched) as few specimens were also negative in the enrichment method but positive in the other methods. $\mathrm{BHI}$ is the ideal agar because the Brucella colonies are easier to identify than on Farrell's agar. RT PCR is not sensitive enough to identify Brucella directly from organs as the pathogen concentration is very low. Culture is still the "gold standard" for the diagnosis of brucellosis.
\end{abstract}

Keywords: Dromedaries; Infected; Brucella melitensis

\section{Introduction}

Dromedary brucellosis is widespread in camel rearing countries and is preliminary caused by Brucella $(B)$. melitensis. The pathogen has been mainly isolated from aborted fetuses, milk, hygromas [1] but rarely from dromedary organs of infected dams [2]. In connection with a serological investigation performed at CVRL, Dubai [3,4], we had the opportunity to culture the pathogen from a great number of organ tissues from 14 dromedaries infected with B. melitensis. The results of these investigations are presented here.

\section{Materials and Methods}

Fourteen non pregnant female dromedaries (Animal ID C1-C14) of different age (14-23 years) were intratracheally and intranasally infected with a $B$. melitensis strain, referred to as EM2 [3] belonging to the genetic group East Mediterranean (former African group). This strain was genotyped with multiple-locus variable number tandem repeat (MLVA) [5]. It was previously isolated from a dromedary placenta. The purpose of this infection experiment was the evaluation of serological tests for the in vivo diagnosis of dromedary brucellosis. All 14 infected dromedaries became serologically as well as blood culture positive and were euthanased 12 months after infection. A full necropsy was performed on all camels and 43 different organs were taken from each dromedary, totalling to 541 specimens from 14 dromedaries. Each panel of specimens included different lymphoid tissues, internal organs, neuronal tissues (brain and spinal cord), joint fluids of both tarsal and carpal joints, and all four udder cisterns. Each specimen was tested for the presence of $B$. melitensis, using 3 methods; the direct, the concentrated and the enrichment culture methods explained hereafter.

Two types of selective Brucella agars were used:

Farrell's media (Brucella medium base CM0169, Oxoid, supplemented with filtered horse serum SHS100, E and O Laboratories, UK and Brucella selective supplement SR0083A, Oxoid) and Brain-Heart-Infusion agar (Brain Heart Infusion CM 1135, Oxoid, with $1 \%$ bacteriological agar and supplemented with filtered horse serum SHS100, E and O Laboratories, UK and Brucella selective supplement, SR0083A, Oxoid).

\section{Direct culture method}

The cut surface of specimens was streaked on the surface of the selective Brucella agar plates and $0.1 \mathrm{ml}$ of joint fluids was cultured by spread plate method on the Brucella selective agars mentioned above.

\section{Concentration culture method}

The specimens were finely minced and transferred into a sterile filter bag (Bag Page, Inter Science, France). Thirty ml of sterile PBS was added to it, then blended and homogenized in a Lab Blender Mixer (Inter Science, France) for 6 minutes at high speed. The filtrate was decanted into sterile $50 \mathrm{ml}$ Falcon tubes and centrifuged at $3000 \mathrm{~g}$ for $30 \mathrm{~min}$. The supernatant was discarded and $0.1 \mathrm{ml}$ of the sediment was streaked on the selective Brucella agar plates.

\section{Enrichment culture method}

A $1.0 \mathrm{ml}$ aliquot of the sediment which was used for the concentration culture method described above was transferred into $7 \mathrm{ml}$ of Trypticase Soy Broth (Merck 1.05459.0500) with Brucella selective supplement SR0083A (Oxoid) in a Greiner tube for incubation at $37^{\circ} \mathrm{C}$ for 6 days. After direct culture the remaining joint fluid was also enriched in Trypticase Soy Broth with Brucella supplements.

\section{Incubation}

All streaked plates and inoculated broth tubes were incubated at $37^{\circ} \mathrm{C}$ in an atmosphere of $5 \% \mathrm{CO}_{2}$ for 6 days. After 6 days incubation, all plates were examined for the growth of typical Brucella colonies. 
The enrichment broth was well homogenized and then $0.1 \mathrm{ml}$ of broth was quadrant streaked on selective Brucella agars. The streaked plates were incubated for another 6 days at $37^{\circ} \mathrm{C}$ in an atmosphere of $5 \% \mathrm{CO}_{2}$. After 6 days of incubation, the plates were examined for growth of typical Brucella colonies.

\section{PCR}

A PCR for the detection of Brucella antigen was only performed on the original specimens and not on the concentrated or enriched specimens. Briefly, a small piece of tissue about $200 \mathrm{mg}$ was placed in an Eppendorf tube containing $2 \mathrm{~mm}$ glass beads (Sigma, US) and $20 \mathrm{ul}$ of proteinase $\mathrm{K}(20 \mathrm{mg} / \mathrm{ml}$ concentration from Qiagen protease,

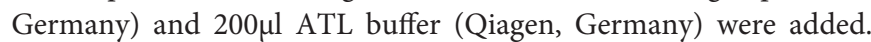
Sample tube was vortexed thoroughly and incubated at $56^{\circ} \mathrm{C}$ for 1 hr. $300 \mu$ buffer AL (Qiagen, Germany) was added and sample tube vortexed for 15 secs after which $500 \mu$ of the sample was transferred to the MagNA Pure automated extraction platform (Roche Diagnostics Ltd, UK). DNA was extracted using MagNA Pure LV DNA extraction kit according to the manufacturer's instructions. The DNA was finally eluted with $100 \mu$ of Magna pure elution buffer. The PCR was performed according to method described by Probert [6], using ABI 7500 DX machine.

\section{Results}

The results of our investigations are shown in Tables 1, 2 and 3.

Table 1 summarizes the results of $B$. melitensis culture and PCR from 43 different dromedary organs of 14 artificially infected dromedaries. From a total of 43 different organs cultured for Brucella bacteria, 21 (49\%) were negative in culture and $22(51 \%)$ harbored the bacteria. Following artificial infection with the pathogen, Brucella bacteria resided mainly in body lymph nodes $(21 \%, 9 / 43)$, udder tissues and lymph nodes $(16 \%, 7 / 43)$ and other tissues $(12 \%, 5 / 43)$. An exception was one tarsal joint fluid, from which Brucella bacteria were isolated in numbers too numerous to count.

The highest isolation percentage of Brucella bacteria was from prescapular lymph nodes dorsales and ventrales (50\% \& 39\% respectively) followed by udder lymph nodes with $29 \%$, lung lymph nodes with $27 \%$ and submandibular lymph nodes with $23 \%$. There was no difference in the isolation frequency in connection with the route of infection.

Table 2 summarizes the results of 3 different culture methods (direct, concentrated, enriched) on 2 different selective agars from organs from 14 necropsied dromedaries. In total 43 organs were tested (Table 1) out of which 22 were cultured positive (51\%, Table 1). Specimens derived from these positive organs gave sometimes inconsistent culture results, as from some dromedaries the same specimens were positive and negative in others.

Table 3 shows the results in detail. There were two dromedaries $\left(\mathrm{C}_{6}, \mathrm{C}_{14}\right)$ from which $B$. melitensis was isolated from only one organ as well as two dromedaries $\left(\mathrm{C}_{2}, \mathrm{C}_{5}\right)$ from which $B$. melitensis was isolated from 10 organs. Despite repeated culture, from 4 no B. melitensis was isolated.

When using direct method (Table 2$)$, only $2(9 \%, 2 / 22)$ organs including tarsal joint fluid were positive on Farrell's agar compared to 6 on BHI agar $(27 \%, 6 / 22)$ including the 2 positive organ/tarsal joint
Table 1: Results of Brucella bacteria culture and PCR from 43 different organs of 14 artificially $B$. melitensis infected dromedaries.

\begin{tabular}{|c|c|c|c|c|c|}
\hline $\begin{array}{c}\text { Organ } \\
\text { number }\end{array}$ & Organs & $\begin{array}{c}\text { Number of } \\
\text { specimens } \\
\text { tested }\end{array}$ & $\begin{array}{l}\text { Number of } \\
\text { positive } \\
\text { specimens } \\
\text { in RT } \\
\text { PCR from } \\
\text { original } \\
\text { specimens }\end{array}$ & $\begin{array}{l}\text { Number of } \\
\text { positive } \\
\text { specimens } \\
\text { in culture }\end{array}$ & $\begin{array}{l}\text { Number of } \\
\text { negative } \\
\text { specimens } \\
\text { in culture }\end{array}$ \\
\hline 1 & Brain & 13 & 0 & $1(7.7 \%)$ & $12(92.3 \%)$ \\
\hline 2 & $\begin{array}{c}\text { Right submandibular } \\
\text { lymph node }\end{array}$ & 13 & 0 & $3(23 \%)$ & $10(77 \%)$ \\
\hline 3 & $\begin{array}{l}\text { Pharyngeal lymph } \\
\text { node }\end{array}$ & 14 & 0 & $2(14.3 \%)$ & $12(85.7 \%)$ \\
\hline 4 & $\begin{array}{l}\text { Left pharyngeal } \\
\text { lymph node }\end{array}$ & 13 & 0 & $2(15.4 \%)$ & $11(84.6 \%)$ \\
\hline 5 & Spinal cord & 14 & 0 & $1(7.1 \%)$ & $13(92.9 \%)$ \\
\hline 6 & Tonsil & 13 & 0 & 0 & $13(100 \%)$ \\
\hline 7 & Trachea & 12 & 0 & 0 & $12(100 \%)$ \\
\hline 8 & $\begin{array}{l}\text { Prescapular lymph } \\
\text { node dorsales }\end{array}$ & 14 & 0 & $7(50 \%)$ & $7(50 \%)$ \\
\hline 9 & $\begin{array}{l}\text { Prescapular lymph } \\
\text { node ventrales }\end{array}$ & 13 & 0 & $5(38.5 \%)$ & $8(61.5 \%)$ \\
\hline 10 & Left Lung & 14 & 0 & $1(7.1 \%)$ & $13(92.9 \%)$ \\
\hline 11 & Right Lung & 13 & 0 & $2(15.4 \%)$ & $11(84.6 \%)$ \\
\hline 12 & $\begin{array}{c}\text { Lymph node } \\
\text { mediastinales medii }\end{array}$ & 11 & 0 & $1(9.09 \%)$ & $10(90.9 \%)$ \\
\hline 13 & Liver & 14 & 0 & 0 & $14(100 \%)$ \\
\hline 14 & Spleen & 14 & 0 & $3(21.4 \%)$ & $11(78.6 \%)$ \\
\hline 15 & Heart & 13 & 0 & 0 & $13(100 \%)$ \\
\hline 16 & $\begin{array}{c}\text { Lymph node } \\
\text { tracheobronchales } \\
\text { medii }\end{array}$ & 13 & 0 & $2(15.4 \%)$ & $11(84.6 \%)$ \\
\hline 17 & $\begin{array}{c}\text { Lymph node } \\
\text { tracheobronchales } \\
\text { sinistrii }\end{array}$ & 12 & 0 & $1(8.3 \%)$ & $11(91.7 \%)$ \\
\hline 18 & Lung Lymph node & 11 & 0 & $3(27.3 \%)$ & $8(72.7 \%)$ \\
\hline 19 & Right kidney & 14 & 0 & 0 & $14(100 \%)$ \\
\hline 20 & Left kidney & 14 & 0 & 0 & $14(100 \%)$ \\
\hline 21 & Urinary bladder & 13 & 0 & 0 & $13(100 \%)$ \\
\hline 22 & Intestine & 13 & 0 & 0 & $13(100 \%)$ \\
\hline 23 & $\begin{array}{l}\text { Lymphocentrum } \\
\text { mesentericum } \\
\text { craniale }\end{array}$ & 13 & 0 & 0 & $13(100 \%)$ \\
\hline 24 & $\begin{array}{l}\text { Lymphocentrum } \\
\text { mesentericum } \\
\text { caudale }\end{array}$ & 11 & 0 & 0 & $11(100 \%)$ \\
\hline 25 & $\begin{array}{l}\text { Small intestinal } \\
\text { lymph node }\end{array}$ & 12 & 0 & 0 & $12(100 \%)$ \\
\hline 26 & Right uterus & 13 & 0 & 0 & $13(100 \%)$ \\
\hline 27 & Left uterus & 13 & 0 & 0 & $13(100 \%)$ \\
\hline 28 & Left ovary & 12 & 0 & 0 & $12(100 \%)$ \\
\hline 29 & Right ovary & 11 & 0 & 0 & $11(100 \%)$ \\
\hline 30 & Left hind udder & 13 & 0 & 0 & $13(100 \%)$ \\
\hline 31 & Right hind udder & 11 & 0 & 0 & $11(100 \%)$ \\
\hline 32 & Left front udder & 13 & 0 & $1(7.7 \%)$ & $12(92.3 \%)$ \\
\hline 33 & Right front udder & 11 & 0 & $1(9.09 \%)$ & $10(90.9 \%)$ \\
\hline 34 & $\begin{array}{l}\text { Left udder lymph } \\
\text { node }\end{array}$ & 14 & 0 & $4(28.6 \%)$ & $10(71.4 \%)$ \\
\hline 35 & $\begin{array}{l}\text { Right udder lymph } \\
\text { node }\end{array}$ & 11 & 0 & $2(18.2 \%)$ & $9(81.8 \%)$ \\
\hline 36 & $\begin{array}{l}\text { Left front udder } \\
\text { cistern }\end{array}$ & 13 & 0 & $2(15.4 \%)$ & $11(84.6 \%)$ \\
\hline 37 & $\begin{array}{l}\text { Right front udder } \\
\text { cistern }\end{array}$ & 11 & 0 & 0 & $11(100 \%)$ \\
\hline
\end{tabular}




\begin{tabular}{|c|c|c|c|c|c|}
\hline 38 & $\begin{array}{c}\text { Left hind udder } \\
\text { cistern }\end{array}$ & 14 & 0 & $2(14.3 \%)$ & $12(85.7 \%)$ \\
\hline 39 & $\begin{array}{c}\text { Right hind udder } \\
\text { cistern }\end{array}$ & 12 & 0 & $1(8.3 \%)$ & $11(91.7 \%)$ \\
\hline 40 & Left tarsal joint fluid & 11 & 0 & 0 & $11(100 \%)$ \\
\hline 41 & Right tarsal joint fluid & 12 & $1(8.3 \%)$ & $1(8.3 \%)$ & $11(91.7 \%)$ \\
\hline 42 & $\begin{array}{c}\text { Left carpal joint fluid } \\
\text { Right carpal joint } \\
\text { fluid }\end{array}$ & 11 & 0 & 0 & $11(100 \%)$ \\
\hline 43 & \begin{tabular}{c} 
Rid \\
\hline
\end{tabular} & 0 & 0 & 0 & $11(100 \%)$ \\
\hline
\end{tabular}

fluid from Farrell's media.

When the concentration method was used, 11 organs were positive on Farrell's agar $(50 \%, 11 / 22)$ and 16 on BHI agar $(73 \%$, $16 / 22$ ). With this method, however, 2 organs cultured positive on Farrell's agar were negative on BHI agar and B. melitensis was only isolated from the right udder cistern on BHI agar with direct method.

There was no isolation difference between Farrell's and BHI media, when the enrichment method was used. A total of 19 organs were B. melitensis positive on both the media (95\%, 19/22). Only 3 organs were negative using this method, but positive with the BHI concentration method $(2 \mathrm{x})$ and BHI direct method (1x).
A total of 282 specimens from 22 positive organs from 14 dromedaries were tested. Table 2 shows the summarized results of how many specimens were positive. The highest isolation success was $40(14.2 \%)$ positive specimens with the enrichment technology.

Except for the right tarsal joint of one dromedary with a joint swelling from which numerous $B$. melitensis colonies were directly isolated, the remaining specimens contained only 2-4 colonies per agar plate on direct culture. When concentration method was used, the number of $B$. melitensis per plate increased to between 2-18 colonies and when enriched, $B$. melitensis was isolated in numbers too numerous to count.

\section{Discussion}

Extreme care must be exercised when working with Brucella as humans are highly susceptible to brucellosis and laboratory infections are not rare. Brucella is an intracellular organism with fastidious growth requirements in vitro, which makes its isolation on culture media difficult. Hence, proper culture techniques and right selection of selective media are mandatory for Brucella isolation. For the isolation of Brucella bacteria, liquid specimens like milk or

Table 2: Isolation of Brucella melitensis from 22 positive organs of 14 artificially infected serological positive dromedaries on 2 different agars by 3 different culture methods.

\begin{tabular}{|c|c|c|c|c|c|c|c|c|}
\hline \multirow{3}{*}{$\begin{array}{l}\text { Organ } \\
\text { Number }\end{array}$} & \multirow{3}{*}{ Organs } & \multirow{3}{*}{$\begin{array}{l}\text { Number of } \\
\text { specimens } \\
\text { tested }\end{array}$} & \multicolumn{6}{|c|}{$\begin{array}{l}\text { Number of specimens positive for Brucella and their percentage on } 2 \text { different Brucella } \\
\text { selective media by } 3 \text { culture methods }\end{array}$} \\
\hline & & & \multicolumn{2}{|c|}{ Direct } & \multicolumn{2}{|c|}{ Concentrated } & \multicolumn{2}{|c|}{ Enrichment } \\
\hline & & & $\begin{array}{l}\text { Farrell's } \\
\text { media }\end{array}$ & $\begin{array}{l}\text { BHI agar } \\
\text { media }\end{array}$ & Farrell's media & $\begin{array}{l}\text { BHI agar } \\
\text { media }\end{array}$ & $\begin{array}{l}\text { Farrell's } \\
\text { media }\end{array}$ & BHI agar media \\
\hline 1 & Brain & 13 & 0 & 0 & 0 & $1(7.7 \%)$ & $1(7.7 \%)$ & $1(7.7 \%)$ \\
\hline 2 & $\begin{array}{l}\text { Right submandibular lymph } \\
\text { node }\end{array}$ & 13 & 0 & 0 & $1(7.7 \%)$ & $1(7.7 \%)$ & $3(23.1 \%)$ & $3(23.1 \%)$ \\
\hline 3 & Pharyngeal lymph node & 14 & 0 & 0 & $2(14.3 \%)$ & $1(7.1 \%)$ & $1(7.1 \%)$ & $1(7.1 \%)$ \\
\hline 4 & Left pharyngeal lymph node & 13 & 0 & 0 & 0 & $2(15.4 \%)$ & $1(7.7 \%)$ & $1(7.7 \%)$ \\
\hline 5 & Spinal cord & 14 & 0 & 0 & 0 & $1(7.1 \%)$ & $1(7.1 \%)$ & $1(7.1 \%)$ \\
\hline 8 & $\begin{array}{l}\text { Prescapular lymph node } \\
\text { dorsales }\end{array}$ & 14 & 0 & $1(7.1 \%)$ & $4(28.6 \%)$ & $3(21.4 \%)$ & $7(50 \%)$ & $7(50 \%)$ \\
\hline 9 & $\begin{array}{l}\text { Prescapular lymph node } \\
\text { ventrales }\end{array}$ & 13 & 0 & 0 & $2(15.4 \%)$ & $4(30.8 \%)$ & $4(30.8 \%)$ & $4(30.8 \%)$ \\
\hline 10 & Left Lung & 14 & 0 & 0 & 0 & 0 & $1(7.1 \%)$ & $1(7.1 \%)$ \\
\hline 11 & Right Lung & 13 & 0 & 0 & 0 & $1(7.7 \%)$ & 2 (15.4\%) & $2(15.4 \%)$ \\
\hline 12 & $\begin{array}{l}\text { Lymph node mediastinales } \\
\text { medii }\end{array}$ & 11 & 0 & 0 & 0 & 0 & $1(9.1 \%)$ & $1(9.1 \%)$ \\
\hline 14 & Spleen & 14 & 0 & 0 & $1(7.1 \%)$ & 0 & 2 (14.3\%) & $2(14.3 \%)$ \\
\hline 16 & $\begin{array}{l}\text { Lymph node } \\
\text { tracheobronchales medii }\end{array}$ & 13 & 0 & $1(7.7 \%)$ & $1(7.7 \%)$ & 0 & $2(15.4 \%)$ & $2(15.4 \%)$ \\
\hline 17 & $\begin{array}{l}\text { Lymph node } \\
\text { tracheobronchales sinistrii }\end{array}$ & 12 & 0 & 0 & 0 & $1(8.3 \%)$ & 0 & 0 \\
\hline 18 & Lung Lymph node & 11 & 0 & 0 & $2(18.2 \%)$ & $1(9.1 \%)$ & $3(27.3 \%)$ & $3(27.3 \%)$ \\
\hline 32 & Left front udder & 13 & 0 & $1(7.7 \%)$ & $1(7.7 \%)$ & $1(7.7 \%)$ & $1(7.7 \%)$ & $1(7.7 \%)$ \\
\hline 33 & Right front udder & 11 & 0 & 0 & 0 & $1(9.1 \%)$ & 0 & 0 \\
\hline 34 & Left udder lymph node & 14 & 0 & 0 & 0 & $4(28.6 \%)$ & $3(21.4 \%)$ & $3(21.4 \%)$ \\
\hline 35 & Right udder lymph node & 11 & 0 & 0 & $1(9.1 \%)$ & $2(18.2 \%)$ & $2(18.2 \%)$ & $2(18.2 \%)$ \\
\hline 36 & Left front udder cistern & 13 & $1(7.7 \%)$ & $1(7.7 \%)$ & $1(7.7 \%)$ & $1(7.7 \%)$ & $2(15.4 \%)$ & $2(15.4 \%)$ \\
\hline 38 & Left hind udder cistern & 14 & 0 & 0 & 0 & 0 & $2(14.3 \%)$ & $2(14.3 \%)$ \\
\hline 39 & Right hind udder cistern & 12 & 0 & $1(8.3 \%)$ & 0 & 0 & 0 & 0 \\
\hline 41 & Right tarsal joint fluid & 12 & $1(8.3 \%)$ & $1(8.3 \%)$ & $1(8.3 \%)$ & $1(8.3 \%)$ & $1(8.3 \%)$ & $1(8.3 \%)$ \\
\hline & Total & 282 & $2(0.7 \%)$ & $6(2.1 \%)$ & $17(6.02 \%)$ & $26(9.2 \%)$ & $40(14.2 \%)$ & $40(14.2 \%)$ \\
\hline
\end{tabular}


Table 3: Number of dromedaries and organs from which Brucella melitensis was isolated; organs denoted by organ number against each dromedary.

\begin{tabular}{|c|c|c|c|}
\hline $\begin{array}{c}\text { Number of } \\
\text { positive organs }\end{array}$ & $\begin{array}{l}\text { Number of } \\
\text { dromedaries }\end{array}$ & Animal ID & $\begin{array}{l}\text { Organs from } \\
\text { which } B \text {. } \\
\text { melitensis was } \\
\text { isolated (see } \\
\text { Table } 1 \text { for organ } \\
\text { number) }\end{array}$ \\
\hline 0 & $4 X$ & $\begin{array}{c}\text { C3, C10, C11, } \\
\text { C12 }\end{array}$ & Nil \\
\hline \multirow{2}{*}{1} & \multirow{2}{*}{$2 x$} & C6 & 8 \\
\hline & & C14 & 41 \\
\hline 2 & $1 X$ & $\mathrm{C} 4$ & 4,8 \\
\hline \multirow[b]{2}{*}{3} & \multirow{2}{*}{$2 x$} & $\mathrm{C} 1$ & $1,3,5$ \\
\hline & & $\mathrm{C9}$ & $8,9,34$ \\
\hline 5 & $1 x$ & $\mathrm{C} 8$ & $2,9,11,14,39$ \\
\hline 6 & $1 x$ & $\mathrm{C} 13$ & $8,9,16,34,36,38$ \\
\hline 7 & $1 X$ & $\mathrm{C} 7$ & $\begin{array}{c}8,9,10,14,18 \\
34,35\end{array}$ \\
\hline \multirow{2}{*}{10} & \multirow{2}{*}{$2 x$} & $\mathrm{C} 2$ & $\begin{array}{c}2,8,9,14,18,32 \\
33,35,36,38\end{array}$ \\
\hline & & $\mathrm{C} 5$ & $\begin{array}{c}2,3,4,8,11,12 \\
16,17,18,34\end{array}$ \\
\hline
\end{tabular}

stomach content can be inoculated straight onto selective media, whereas tissue samples should be finely minced and homogenized in a blender and aliquots used for culture as Brucella bacteria are intracellular organism. Although Brucella melitensis grows well on blood agar, most specimens tested may contain many different bacterial and sometimes fungal species and therefore selective media are required for the isolation of this pathogen. We were fortunate with our investigation, as all 43 organs collected from each euthanased dromedary camel were immediately cultured after necropsy.

Our investigations showed that whenever testing a carcass for brucellosis, specimens should be taken from at least 22 different organs mentioned in Table 2, as it is unpredictable which organ may harbor the pathogen.

For the culture of Brucella bacteria from organs, we choose Farrell's and Brain-Heart-Infusion (BHI) agars which possess the same antibiotics and antifungal ingredients which are in the selective supplement SR0083A from Oxoid.

Even though, the selective supplements were the same for BHI and Farrell's media, it was observed that BHI media was less inhibitory to Brucella bacteria compared to Farrell's media. The Brucella colonies were easier to identify on BHI media as the colonies appear larger, honey-comb colored and translucent in white light after 6 days incubation. On Farrell's media the colonies appear small or tiny after 6 days of incubation leading to chances of not detecting them. These differences can only be explained by the different compositions of Farrell's and BHI media. BHI media contains brain infusion solids and di-sodium phosphate which are not added to the Farrell's media.

Although there was no isolation difference found between the enrichment technology with Farrell's and BHI agars, the ideal method for the isolation of $B$. melitensis from dromedary organs is the enrichment method using BHI agar as the Brucella bacteria are easier to detect.

However, also the enrichment method did not always detect all Brucella-positive organs. Therefore, it is proposed to include all three methods direct, concentration and enrichment methods when Brucella isolation from organs is required.

Interestingly, when 282 specimens from 22 positive organs were tested directly with RT PCR, all results were negative except one tarsal joint fluid. From this tarsal joint of one infected dromedary which was severely swollen, numerous $B$. melitensis colonies were directly isolated. The low concentration of Brucella organisms in original specimens is the reason why all RT PCR were negative. The low sensitivity of Brucella RT PCR has been described previously [7]. RT PCR on concentrated or enriched specimens was not performed as it was obvious that these 2 culture methods alone would identify the positive specimens.

\section{References}

1. Wernery U, Kinne J, Schuster RK. Camelid Infectious Disorders. OIE Book. $2014 ; 135-147$

2. Wernery $U$, Kinne J, Johnson M, Nagy P. Where do Brucella organisms hide in serologically positive lactating dromedaries. In Proc. Int. Camel Conference, 16.-17.2; College of Veterinary and Animal Science, Rajasthan Agricultural University, Bikaner, India. 2007; 68-70.

3. Söllner NK. Evaluation of serological tests for the diagnosis of Brucellosis in Brucella melitensis infected dromedary camels. Doctoral Thesis, Veterinary Faculty of Leipzig University, Germany. 2018.

4. Söllner NK, Kinne J, Schuster RK, Johnson B, Jose Sh, Raghavan R, Syriac $\mathrm{G}$, John J, et al. Evaluation of serological tests for the diagnosis of brucellosis in Brucella melitensis experimentally infected dromedary camel. J. Camel Pract. and Research. 2018; 25: 25-28.

5. Gyuranecz M, Wernery $U$, Kreizinger Z, Juhasz J, Felde $O$, Nagy $P$ Genotyping of Brucella melitensis strains from dromedary camels (Camelus dromedarius) from the United Arab Emirates with multiple-locus variablenumber tandem repeat analysis. Veterinary Microbiology. 2016; 186: 8-12.

6. Probert WS, Schrader KN, Khuong NY, Bystrom SL, Graves MH. Realtime multiplex PCR assay for detection of Brucella spp, B. abortus, and B. melitensis. Journal of Clinical Microbiology. 2004; 42: 1290-1293.

7. Von Hieber D. Investigation of occurrence and persistence of brucellosis in female camel dams (Camelus dromedarius) and their calves. Thesis, Universität Ulm, Germany. 2010.
Austin J Vet Sci \& Anim Husb - Volume 5 Issue 2 - 2018 ISSN: 2472-3371 | www.austinpublishing group.com Wernery et al. () All rights are reserved
Citation: Johnson B, Kinne J, Jose Sh, Pfeffer M, Shanmugaraja R, Pandarakandy Sh, et al. Recovery of Brucella melitensis from Artificially Infected Dromedaries. Austin J Vet Sci \& Anim Husb. 2018; 5(2): 1046. 